\title{
Skin and coat traits in sheep in Brazil and their relation with heat tolerance
}

\author{
Concepta McManus • Helder Louvandini • Rosilene Gugel • \\ Luiz Cláudio Bastos Sasaki • Eliandra Bianchini • Francisco Ernesto Moreno Bernal • \\ Samuel Rezende Paiva • Tiago Prado Paim
}

Accepted: 18 July 2010 /Published online: 2 August 2010

(C) Springer Science+Business Media B.V. 2010

\begin{abstract}
The objective of this study was to evaluate and compare physical parameters in groups of sheep with different phenotypic characteristics in the Centre-west region of Brazil. Five groups of sheep, with nine animals per group, were selected, three groups of Santa Inês animals with different coat colours (white, brown and black), one group with crossbred animals (Santa Inês $\times$ Bergamasca) and one group with animals of the Bergamasca breed. The following traits were evaluated: coat thickness, number and length of hair, pigmentation level in the coat and the skin as well as the percentage area of sweats glands in the skin tissue, carried out by histological analysis. The number of hairs and the area of sweats glands were not significantly different between the evaluated groups. The Bergamasca breed showed low pigmentation of the skin and long hairs. The levels of pigmentation of the hair and of the skin were highly correlated. Between the Santa Inês groups, the group with white hair showed the better parameters for heat adaptation, while the brown hair group showed the lower heat adaptation when compared with another hair breed groups.
\end{abstract}

\section{McManus $(\bowtie)$}

Department of Animal Production,

Av. Bento Gonçalves,

7712 - Caixa Postal 15100 - CEP 91540-000, Porto Alegre,

RS, Brazil

e-mail: concepta@unb.br

H. Louvandini • R. Gugel • L. C. B. Sasaki • E. Bianchini •

F. E. M. Bernal • T. P. Paim

Faculdade de Agronomia e Medicina Veterinária,

Universidade de Brasília,

Brasília, DF 70910-900, Brazil

\section{S. R. Paiva}

EMBRAPA Recursos Genéticos e Biotecnologia,

PqEB, Final W5 Norte,

Brasília, DF 70770-900, Brazil

e-mail: Samuel@cenragen.embrapa.br
Keywords Bergamasca · Pigmentation · Sweat glands · Hair $\cdot$ Santa-Inês $\cdot$ Wool

\section{Introduction}

Sheep rearing is considered to be an important economic activity in various regions of the world for meat and wool production or for wool and hides. Thermal stress can affect production indices in tropical regions (Silanikove 2000), with well-adapted animals being characterised by maintenance, or minimum loss of production during stress, high reproductive efficiency and disease resistance as well as longevity and low mortality rates (West 2003).

Recently, Marai et al. (2007) published a revision on this subject. Several traits can be used to test adaptation of animals to heat including physical and physiological parameters (Silva 2000). An individual animal's susceptibility to heat stress is influenced by several factors including species, colour, condition score or finish, temperament, sex, coat thickness, and previous exposure (Brown Brandl 2009). Properties of the skin and coat also affect energy exchange including colour, density, diameter, depth, transmissivity and heat absorption (Bianchini et al. 2006).

Breed comparison is one of the bases of animal breeding. Anatomical studies of skin in cattle of White Fulani, N'Dama, Muturu and Holstein cattle in Nigeria showed differences between regions and breeds for density and depth of follicular capillaries (Amakiri and Hill 1975). Some authors have studied the effect of the structure of sheep skin on leather (Jacinto et al. 2004) and wool quality (Li et al. 2006). Bertipaglia et al. (2007) also showed that skin traits affect heat tolerance in animals. Cattle studies have shown a major gene effect in some Crioula breeds which causes the expression of extremely short coats (Olson et al. 1997a; b; Lucena and Olson 2000; Olson et al. 2003) which may be 
responsible for part of the resistance of these animals. Contrary to this, Acharya et al. (1995) showed that Indian goats with long light coloured coats were more resistant.

There is a lack of information on characterization of skin and coat traits in Brazilian sheep, especially hair breeds. Silva (2000) suggested a series of traits associated with heat tolerance. Type and colour of the coat are important (Turner 1984; Finch et al. 1984), animals with dark coats and therefore higher absorption of thermal radiation being more susceptible to thermal radiation than animals with light coats (Silva 1998). In the tropics, studies have shown slower growth rates with dark coated animals (Robertshaw 1986), but according to Cunha et al. (2004), Brazilian Santa Ines sheep farmers have preferred black-coated animals and other coat colours are disappearing.

Knowledge of certain traits related to animal adaptation to regional climates may AID sheep farming development which is new to the central West region of Brazil. This study aimed to evaluate and compare different coat and skin traits in phenotypically different sheep.

\section{Material and methods}

This study was carried out in the Sheep management Centre of the University of Brasilia, situated at $15^{\circ} 47^{\prime} \mathrm{S}$ e $47^{\circ} 56^{\prime} \mathrm{W}$ Gr., in the Federal District, Brazil. Five groups of animals (with nine animals per group) were studied. There were three groups of Santa Ines sheep with three different coat colours (White, Brown and Black). The fourth group was with animals of the Bergamasca (a white Italian wool breed, adapted to the Brazilian climate) and the fifth crossbred animals (Bergamasca $\times$ black Santa Ines). This last group had wool on the back and legs and generally a dark coat.

The traits examined included coat thickness, number of hairs per square centimeter and their length, reflectance of skin and coat and area occupied by sweat glands. Coat thickness was measured using an adipometer in 10th of a millimeter. Reflectance was measured using a reflectometer (Silva 2000) where reflected light is captured by a light sensitive photoresister. This gives an indirect reading of skin and coat pigmentation. Hairs were collected in a $1-\mathrm{cm}^{2}$ region of the upper shoulder, counted and measured using a paquimeter.

Skin fragments were collected in the upper part of the shoulder using a biopsy punch with a $1 \mathrm{~cm}$ internal diameter, after application of a local anaesthetic (Lidocaine Cloridrate $2 \%$ ). These were then fixed in formaldehyde and later processed in histotechnique (omadm-20), dehydrated in increasing concentrations of ethanol $(70 \%, 90 \%$ and $100 \%$ ), diaphanized in xylol and infiltrated in liquid paraffin. This was then cut in $4 \times 4 \mu \mathrm{m}$ thick sections using a microtome (Leica model RM 2025) for slide mounting and coloured with hematoxylin and eosin.
An AxioSkop (Zeiss) microscope coupled with a CCD digital colour camera (Sony model DXC-107) and computer with board for digital capture Pixel View Play TV $(320 \times 240$ pixels $)$ for image capture. Four secretor portions of the sweat glands were visualised and measured per slide. Measurements were taken using a programme for morphological measurements (Image-Pro Plus ${ }^{\circledR}$ version 5.0, Media Cybernetics, L.P.).

Statistical analyses were carried out using the Statistical Analysis System ${ }^{\circledR}$ package (SAS $\left.{ }^{\circledR}\right)$.The general linear model included group (five) as fixed effects. Other analyses included correlations and principal components based on the parameters measured and included analyses in conjunction with physiological traits measured in McManus et al. (2009a). Scores were transformed by square root and percentages by arc sine.

\section{Results}

Analysis of variance results are shown in Table 1, with phenotypic group significantly affecting all traits measured. Hair length was highly variable $(38.96 \%)$ and varied between groups $(P<0.001)$.

Means per group are shown in Table 2. The brown- and black-coated animals, as well as the crossbreds, showed higher pigmentation in their skin. The white-coated animals (Santa Ines and Bergamasca) showed significantly lower skin pigmentation, while the Bergamasca showed significantly lower pigmentation than the white Santa Ines. In terms of coat length, the Bergamasca sheep had longer hairs than the other groups (crosses and Santa Inês).

Table 3 shows the correlations between the traits examined with pigmentation in skin and coat having a positive correlation. Most correlations between physical and physiological traits were low to medium (Table 4). Sweating rate was positively correlated with RR, TR and ST, meaning that animals with higher rectal and skin temperatures sweated more and had heavier breathing. This

Table 1 Summary of analysis of variance for skin and coat traits in sheep in Brazil

\begin{tabular}{lllllll}
\hline & $\begin{array}{l}\mathrm{CT} \\
(\mathrm{mm})\end{array}$ & $\begin{array}{l}\mathrm{CR} \\
(0-10)\end{array}$ & $\begin{array}{l}\mathrm{SR} \\
(0-10)\end{array}$ & $\begin{array}{l}\mathrm{HL} \\
(\mathrm{mm})\end{array}$ & $\begin{array}{l}\text { NH } \\
\left(\text { hairs } / \mathrm{cm}^{2}\right)\end{array}$ & $\begin{array}{l}\text { Area } \\
(\%)\end{array}$ \\
\hline Group & $*$ & $* * *$ & $* * *$ & $* * *$ & $* * *$ & $* * *$ \\
CV (\%) & 15.7 & 6.01 & 6.35 & 38.96 & 22.26 & 21.82 \\
Mean & 5.32 & 7.68 & 7.06 & 3.21 & 310.09 & 21.73 \\
\hline
\end{tabular}

$C T$ coat thickness, $C R$ coat reflectance, $S R$ skin reflectance; $H L$ hair length, $\mathrm{NH}$ number of hairs per $\mathrm{cm}^{2}$, Area sweat gland area, Group group of animals differentiated by genetic group and coat colour, $\mathrm{CV}$ coefficient of variation

$* P<0.05 ; * * * P<0.001$ 
Table 2 Means of skin and coat traits in sheep by group in Brazil

\begin{tabular}{|c|c|c|c|c|c|c|c|}
\hline Group & $\mathrm{CT}(\mathrm{mm})$ & CR $(0-10)$ & SR $(0-10)$ & HL (mm) & $\mathrm{NH}$ (hairs $\left./ \mathrm{cm}^{2}\right)$ & Area $(\%)$ & $\mathrm{P} 1$ \\
\hline Black & $4.79 \mathrm{~b}$ & $8.65 \mathrm{a}$ & $8.01 \mathrm{a}$ & $1.46 \mathrm{~b}$ & $279.25 c$ & $23.59 b$ & $-1.62 b$ \\
\hline Brown & $5.52 \mathrm{ab}$ & $8.35 \mathrm{~b}$ & $7.51 \mathrm{~b}$ & $1.36 \mathrm{~b}$ & $307.66 \mathrm{bc}$ & $22.37 b$ & $-1.49 b$ \\
\hline White & $4.76 c$ & $6.22 \mathrm{~d}$ & $6.58 \mathrm{c}$ & $1.26 \mathrm{c}$ & $314.23 b$ & $26.15 \mathrm{a}$ & $-5.07 \mathrm{a}$ \\
\hline Crossbred & $5.54 \mathrm{ab}$ & $8.57 \mathrm{ab}$ & $7.62 \mathrm{~b}$ & $2.20 \mathrm{~b}$ & $346.67 \mathrm{a}$ & $18.86 \mathrm{c}$ & $0.36 \mathrm{c}$ \\
\hline Bergamasca & $6.00 \mathrm{a}$ & $6.94 \mathrm{c}$ & $5.82 \mathrm{~d}$ & $9.56 \mathrm{a}$ & - & $18.08 \mathrm{c}$ & $1.63 \mathrm{~d}$ \\
\hline
\end{tabular}

Means followed by different letters in the same column differ according to Tukey test at $5 \%$ significance

$C T$ coat thickness, $C R$ coat reflectance, $S R$ skin reflectance $H L$ hair length, $N H$ number of hairs per $\mathrm{cm}^{2}$, Area sweat gland area, $P 1$ first principal component

was also positively correlated with longer hairs and lower PCV and TPP.

Figure 1 shows the principal component analysis for the traits studied here together with physiological traits measured in the same animals (McManus et al. 2009a). The Bergamasca animals were excluded from this analysis. Animals with longer hairs, thicker coats had higher sweating rates, respiratory rates and skin temperatures. This was accompanied by low packed cell volume. These two autovectors explained $60 \%$ of the total variation between the traits examined.

\section{Discussion}

As groups were selected due to coat colour, many of the significant differences found between coat traits were expected. The white group showed thinner coats which may be explained by the high quantity of wool in other groups (clearly seen in the crossbred and Bergamasca animals). Other authors also found high CVs for skin traits in sheep (Jacinto et al. 2004). This is also a reflection of larger hairs found in crossbred and Bergamasca sheep.

Animals with thicker and denser coats have greater difficulty in eliminating latent heat via cutaneous evaporation (Holmes 1981). According to Stone et al. (1992), coat thickness alters the quantity of metabolizable energy

Table 3 Correlations between skin and hair parameters in sheep in Brazil

\begin{tabular}{lrrrrr}
\hline & CT & CR & SR & HL & NH \\
\hline CR & -0.09 & & & & \\
SR & -0.28 & 0.73 & & & \\
HL & 0.37 & -0.40 & -0.71 & & \\
NH & -0.33 & -0.05 & -0.16 & 0.17 & \\
Area & -0.08 & -0.01 & 0.33 & -0.37 & -0.44 \\
\hline
\end{tabular}

$C T$ coat thickness, $C R$ coat reflectance, $S R$ skin reflectance, $H L$ hair length, $N H$ number of hairs per $\mathrm{cm}^{2}$, Area sweat gland area necessary for maintenance, as the difficulty in liberating latent body heat causes the body to use compensatory mechanisms which lead to energy generation, this being unfavourable for production animals.

Yeates (1954) showed that thin, smooth skin was associated with resistance to heat stress and that thick skin would be a survival threat in environments where the temperature was above $40.5^{\circ} \mathrm{C}$. Finch et al. (1984) also showed that thick hairy skins were associated with resistance to body heat dissipation. The method used in the present study evaluated coat thickness (skin plus covering hairs) which means a more detailed analysis of this point cannot be made.

Coat colour is important in determining heat tolerance in animals. McManus et al. (2009a) looking at physiological traits in the same groups of sheep as here showed that white Santa Inês sheep had lower heart and breathing rates and rectal temperatures than the other groups showing better heat adaptation.

In cattle, tropical breeds have more pigment in the skin compared to temperate breeds (Amakiri 1979). Bianchini et al. (2006) noted significant differences between skin and hair traits in native and exotic cattle breeds in Brazil. A similar situation was observed in this study. Tropical breeds of cattle have a highly pigmented skin and a white or light coloured coat, which is a consequence of natural selection. This helps to protect the tissues under the skin of the animal from short wave ultraviolet radiation which easily penetrates the thin skin of temperate animals (Silva et al. 2003). In this study, the darker coated sheep also had darker coloured skin. The "ideal" for animals reared in the tropics would be a dark skinned animal with a light coloured coat. Animals with lighter coats reflect more light (Silva et al. 2003) and absorb between $40 \%$ and $50 \%$ less radiation than those with dark coats. The dark skin would impede the penetration of ultraviolet rays and white hairs reflect heat due to infra-red radiation. In this case, animals with light coats also tended to have light skin. There is therefore a conflict between these traits in terms of heat tolerance. 
Table 4 Correlations between physical and physiological traits linked to heat tolerance in Brazilian sheep

\begin{tabular}{|c|c|c|c|c|c|c|c|}
\hline & $\mathrm{CT}$ & $\mathrm{CR}$ & SR & $\mathrm{HL}$ & $\mathrm{NH}$ & Area & SW \\
\hline HR & 0.08 & -0.1 & -0.07 & 0.14 & -0.15 & -0.08 & 0.11 \\
\hline $\mathrm{RR}$ & 0.22 & -0.02 & -0.27 & 0.42 & 0.15 & -0.31 & 0.52 \\
\hline $\mathrm{TR}$ & -0.07 & 0.06 & -0.04 & 0.1 & 0.28 & -0.26 & 0.35 \\
\hline ST & 0.04 & -0.19 & -0.4 & 0.37 & 0.15 & -0.26 & 0.51 \\
\hline PCV & 0.04 & 0.16 & 0.27 & -0.27 & 0.00 & 0.26 & -0.13 \\
\hline ТPP & 0.00 & 0.22 & 0.39 & -0.35 & -0.08 & 0.22 & -0.26 \\
\hline LEUK & -0.08 & 0.22 & 0.19 & -0.12 & 0.25 & 0.02 & 0.08 \\
\hline HEM & -0.12 & 0.23 & 0.38 & -0.46 & -0.03 & 0.39 & -0.29 \\
\hline $\mathrm{HB}$ & -0.02 & 0.18 & 0.37 & -0.32 & -0.11 & 0.36 & -0.04 \\
\hline $\mathrm{MCV}$ & 0.32 & -0.12 & -0.2 & 0.27 & 0.12 & -0.20 & 0.37 \\
\hline $\mathrm{MCHC}$ & 0.04 & 0.1 & 0.01 & 0.05 & 0.03 & 0.19 & -0.24 \\
\hline DIF & -0.08 & 0.25 & 0.44 & -0.38 & -0.04 & 0.18 & -0.43 \\
\hline
\end{tabular}

$H R$ heart rate (beats per minute), $R R$ respiratory rate (breaths per minute), $T R$ rectal temperature $\left({ }^{\circ} \mathrm{C}\right), S T$ skin temperature, $\left({ }^{\circ} \mathrm{C}\right), P C V(\%)$ packed cell volume, TPP total plasma protein $(\mathrm{g} / 100 \mathrm{~mL})$, LEUK leukocytes $\left(\times 10^{3} / \mathrm{mm}^{3}\right), H E M$ red blood cells $\left(\times 10^{6} / \mathrm{mm}^{3}\right), H B$ haemoglobin $(\mathrm{g} / 100 \mathrm{~mL})$, $M C V$ mean corpuscular volume (fl), $M C H C$ (\%) mean corpuscular haemoglobin concentration, $C T$ coat thickness (mm), $C R$ coat reflectance $\left(A^{\circ}\right), S R$ skin reflectance $\left(A^{\mathrm{o}}\right), H L$ hair length $(\mathrm{mm}), N R$ number of hairs, Area sweat gland area $\left(N^{\mathrm{o}}\right.$ per $\left.\mathrm{cm}^{2}\right), S W$ sweating rate $\left(\mathrm{g}\right.$ per $\mathrm{m}^{2}$ per min), DIF difference between rectal and skin temperatures $\left({ }^{\circ} \mathrm{C}\right)$.

Gebremedhin et al. (2008) studying coat colour differences in Angus cattle found that white cattle sweated more and had lower body temperatures than black-coated animals.

Coat length and thickness are important traits linked to animal adaptation in the tropics, where longer hair is linked to animals more affected by heat stress (Yeates 1955). Silva (1998) has shown that number of hairs per unit area is important in protection of the skin against ultraviolet radiation. Other studies have shown that a lower number of hairs per unit area facilitate wind penetration of the coat, removed air

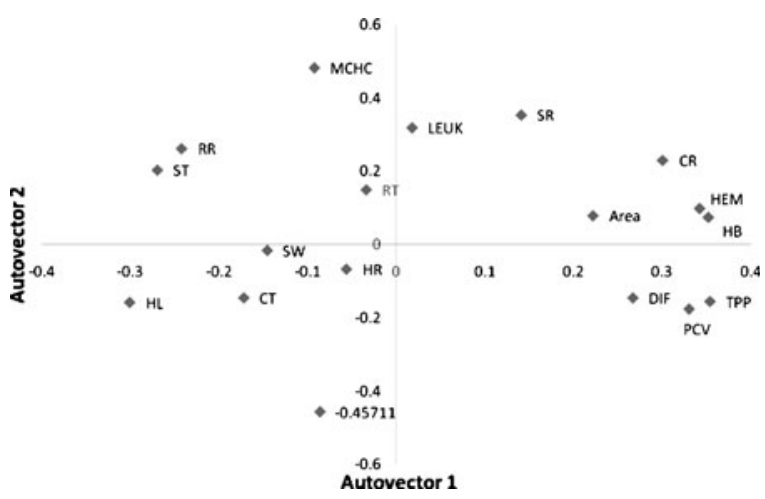

Fig. 1 Principal components for skin, coat and physiological traits in sheep $H R$ heart rate (beats per minute), $R R$ respiratory rate (breaths per minute), $T R$ rectal temperature $\left({ }^{\circ} \mathrm{C}\right), S T$ skin temperature, $\left({ }^{\circ} \mathrm{C}\right), P C V$ (\%) packed cell volume, TPP total plasma protein $(\mathrm{g} / 100 \mathrm{~mL}), L E U K$ leukocytes $\left(\times 10^{3} / \mathrm{mm}^{3}\right), H E M$ red blood cells $\left(\times 10^{6} / \mathrm{mm}^{3}\right), H B$ haemoglobin $(\mathrm{g} / 100 \mathrm{~mL}), M C V$ mean corpuscular volume (fl), MCHC (\%) mean corpuscular haemoglobin concentration, $C T$ coat thickness (mm), $C R$ coat refelectance $\left(A^{\circ}\right), S R$ skin reflectance $\left(A^{\mathrm{o}}\right), H L$ hair length (mm), $N R$ number of hairs, Area sweat gland area $\left(N^{\circ}\right.$ per $\left.\mathrm{cm}^{2}\right)$, $S W$ sweating rate (g per $\mathrm{m}^{2}$ per minute). $D I F$ - difference between skin and rectal temperatures $\left({ }^{\circ} \mathrm{C}\right)$ trapped between the hairs and favouring heat transfer (Gebremedhin et al. 1997). In this study, the crossbreds had the highest number of hairs per square centimeter (Table 2) and black the lowest number but were not significantly different within the Santa Inês breed. The Bergamasca were not measured for this trait as the wool mixed with the hairs. Longer hairs also caused a transfer of heat from skin to interior of the body producing negative effects on blood parameters. More heat conducted by hair than by air. With increased number and thicker hairs more energy is transferred by the coat. Coats with thick, short, packed hairs produce a high latent and sensible heat flux from the skin to the coat surface. The greater resistance of a thick coat contributes to increased thermal stress (Turnpenny et al. 2000). Thick coats also prevent evaporation from the skin (Silva 2000).

Hair number is also highly correlated to the number of apocrine glands (Marai and Haeeb 2009). A higher number of hairs mean the animals have a higher number of sweat glands and better adaptation to hot climates. For sheep, in reference to morphological traits of hair follicles, it can be seen that primary follicles which give rise to hairs and heterotypic strands develop first followed by secondary follicles which give rise to wool (Silva 2000). In this case, wool is not associated with a sweat gland thereby not being used for quantification of these glands. Sweating rate is subject to considerable variation within the same individual and there has been shown to be differences between breeds and groups of animals depending on the environment in which they can be found (McManus et al. 2009b).

Müller (1982) showed that higher sweat gland volume is related to higher sweat production, and thereby infers better 
adaptation to tropical climates. The Bergamasca and crosses had the smallest glands and white Santa Ines the largest.

Morphological traits are important as they directly affect heat exchange mechanisms such as cutaneous convection, radiation and loss of latent heat to the environment by cutaneous evaporation (Maia et al. 2003). The Bergamasca animals had the thickest coats, low skin pigmentation, longer hairs and lowest area occupied by sweat glands. All of these factors lead to a less well-adapted animal to heat stress. The crossbred animals also showed traits linked to a lower adaptation to heat if compared to the Santa Inês animals. This is in agreement with conclusions obtained from analyses of physiological parameters in the same animals (McManus et al. 2009a), where white-coated animals were best adapted. The traits involved may include short, thin coats, high number of sweat glands and low skin pigmentation.

According to Paiva et al. (2005), the Santa Inês are genetically close to the Bergamasca, this relationship being closer than any other genetic relationship with other hair sheep. The same authors show that Santa Ines sheep in the Northeast and Centre-west regions of Brazil can be classified in two sub-populations, with significantly different genetic standards. According to these authors, crosses between the original Santa Inês and rams of the Suffolk breed were carried out in the Northeast to improve conformation of the breed and then successive selections for lack of wool, leading to an increase in the number of black and brown Santa Ines available from this region. This crossbred was also considered pure "new" Santa Inês, a larger animal with improved carcass quality. The Santa Ines breeders have concentrated their production on this animal with dark coat as standard for the breed. Whitecoated animals are no longer well accepted by the farmers due to preconceptions on their production value and the "fad" for black or brown animals, whereas a better strategy would be the use and selection of white-coated animals to improve heat tolerance. How these selection actions will affect future responses of the breed to heat tolerance and disease resistance has yet to be seen. Important factors such as scrapie susceptibility, never before reported in naturalised sheep in Brazil, have now been documented in Santa Ines sheep (Ianella et al. 2009; Sotomaior et al. 2008).

Nevertheless, animal production is not related to a single trait or characteristic, but includes adaptation to the environment, disease and parasite resistance, nutritional parameters, production and body indices as well as reproductive traits, among others.

The positive correlations suggest when the animals absorb environmental heat causing a rise in skin temperature, this activates homeothermic mechanisms. For example an increase in body temperature due to thicker coat, longer hairs causing increase in body temperature causes stress which therefore leads to the liberation of adrenalin which may cause LEUK increase (Swenson and Reece 1996). These reactions also cause increase in RR, since sweating and polypneia are important heat regulatory processes in sheep (Marai et al. 2007). A larger area of sweat glands and higher coat reflectance led to lower skin temperature, and a higher difference between rectal and skin temperatures. A subgroup of animals with high skin and coat reflectance also showed low MCV.

\section{Conclusions}

Phenotypic groups of Santa Ines sheep differ in terms of physical factors which affect heat tolerance and white sheep showing more heat-resistant traits. Animals with longer hairs, thicker and darker coats were under more stress (sweating more, higher rectal temperatures and respiratory rates). Wool sheep were shown to have traits that are less adaptive to tropical climates.

Acknowledgements The authors would like to acknowledge CNPq (INCT) for research scholarships as well as FAPDF and FINATEC for financial aid.

\section{References}

Acharya, R. M., Gupta, R. M., Sehgal, J. P. E Singh, M. 1995. Coat characteristics of goats in relation to heat tolerance in the hot tropics. Small Ruminant Research, 18, 245-248

Amakiri, S.F. 1979. Melanin and DOPA-positive cells in the skin of tropical cattle. Acta Anatomica, 103, 434-444.

Amakiri, S.F., Hill, D.H. 1975. Hair follicle measurements in some tropical and temperate breeds of cattle in Nigeria. International Journal of Biometeorology, 19, 115-121.

Bertipaglia, E.C.A., da Silva, R.G., Cardoso, V., Fries, L.A. 2007. Hair coat characteristics and sweating rate of Braford cows in Brazil. Livestock Science, 112, 98-108.

Bianchini, E., C. McManus; C.M. Lucci; M.C.B. Fernandes; E. Prescott; A.S. Mariante and A.A. Egito. 2006 Características corporais associadas com a adaptação ao calor em bovinos naturalizados brasileiros. Pesquisa agropecuaria brasileira, 41, 1443-1448.

Brown Brandl, T.M. 2009. Overview of the Progress in Reducing Environmental Effects on Cattle. In: Proceedings American Dairy Science Association 18th Discover Conference, 2-5 Nov 2009, Nashville, IN

Cunha, E.A. Bueno, M.S. Santos, L.E. 2004 Santa Inês: a produção intensiva de carne. Revista O Berro, 63, 6-10

Finch, V.A.; Bennet, I.L.; Holmes, C.R. 1984 Coat colour in cattle: effect on thermal balance, behaviour and growth, and relationship with coat type. Journal of Agricultural Science, 102, 141-147.

Gebremedhin, K.G., Ni, H., Hillman P.E. 1997 Temperature profile and heat flux through irradiated fur layer. In: Proceedings of the International Livestock Environment Symposium, Bloomington, MN. v.1, p.226-233. 
Gebremedhin, K.G., Hillman, P.E., Lee, C.N., Collier, R.J., Willard, S. T., Arthington, J.E., Brown Brandl, T.M. 2008. Sweating rates of dairy cows and beef heifers in hot conditions. Transactions ASABE. 51, 2167-2178.

Holmes, C.W. 1981. A note on the protection provided by the hair coat or fleece of the animal against the thermal effects of simulated rain. Animal Production, 32,225-226.

Ianella, P.; McManus, C. P.; Caetano, A. R.; Martins, C. F.; Souza, C. J. H. de; Facó, O.; Azevedo, H. C.; Carneiro, P. S.; Paiva, S. R. 2009. Avaliação dos polimorfismos do gene PRNP ligados à Scrapie clássica em núcleos de conservação de ovinos no Brasil. In: Proceedings of the 7th Simposio de Recursos Genéticos para América Latina y El Caribe, p. 265-266.

Jacinto, M.A.C., Silva Sobrinho, A.G., Costa, R.G. 2004. Anatomicalstructural characteristics of wool-on and non-wool sheep skins related to the physical-mechanic leather aspects. Revista Brasileira de Zootecnia, 33,1001-1008.

Li, L., Godwin, I., Liu, S.M., Oddy, V.H., Nolan, J.V. 2006 Skin characteristics and skin protein composition of Merinos differing in estimated breeding values for wool growth and fed at above and below maintenance Australian Journal of Experimental Agriculture, 46,937-941.

Lucena, C., and T. A. Olson. 2000. Effect of hair coat type on rectal temperatures, milk production and calving interval in Holstein $\mathrm{X}$ Carora crossbred cows. In: Proc. 10th Congreso Venezolano de Zootecnia, Guanare, Venezuela. p. 84.

Maia, A.S.C.; Silva, R.G.; Bertipaglia, E.C.A. 2003 Características do pelame de vacas Holandesas em ambiente tropical: um estudo genético e adaptativo. Revista Brasileira de Zootecnia. 32, 843-853.

Marai, I., Haeeb, A. 2009 Buffalo's biological functions as affected by heat stress - A review. Livestock Science, 127, 89-109.

Marai, I.F.M., El-Darawany, A.A., Fadiel, A., Abdel-Hafez, M.A.M. 2007 Physiological traits as affected by heat stress in sheep-A review Small Ruminant Research, 71: 1-12

McManus, C.M., Paludo, G.R., Louvandini, H., Gugel, R., Sasaki, L. C.B., Paiva, S.R. 2009a Heat tolerance in Brazilian sheep: physiological and blood parameters. Tropical Animal Health and Production. 41,95-101,

McManus, C.M., Prescott, E., Paludo, G.R., Bianchini, E., Louvandini, H., Mariante, A.S. 2009b. Heat tolerance in naturalized Brazilian cattle breeds. Livestock Science. 120, 256-264

Müller, P.B., 1982 Bioclimatologia aplicada aos animais domésticos. $2^{a}$ Edição rev. e atual. Porto Alegre. Ed. Sulina. 1982. 158 p.

Olson, T. A., C. Lucena, C. C. Chase, Jr., and A. C. Hammond. 2003. Evidence of a major gene influencing hair length and heat tolerance in Bos taurus cattle. Journal of Animal Science, 81,80-90,

Olson, T.A. Hammond, A. C. and Chase C. C. 1997a. GM 20. Evidence for the existence of a major gene influencing hair length and heat tolerance in Bos taurus Cattle. Archivos Latinoamericanos de Produccion Animal, 5(Supl. 1), 521-523

Olson, T.A., A.C. Hammond, and C.C. Chase, Jr. 1997b. Evidence for the existence of a major gene influencing hair length and heat tolerance in Senepol cattle. Journal of Animal Science, 75 (Suppl. 1): 147

Paiva, S.R., Silvério, V.C., Egito, A.A., McManus, C., Faria, D.A., Mariante, A.S., Castro, S.R., Albuquerque, M.S.M., Dergam, J. A. 2005 Genetic variability of the Brazilian hair sheep breeds. Pesquisa agropecuaria brasileira. 40, 887-893.

Robertshaw, D. 1986. Physical and physiological principles of adaptation of animals to the tropics. In: Proceedings of the Simpósio Internacional de bioclimatologia animal nos trópicos: pequenos e grandes ruminantes, EMBRAPA-DIE, p.8794.

Silanikove, N. 2000 Effects of heat stress on the welfare of extensively managed domestic ruminants, Livestock Production Science, 67, 1-18

Silva, R.G. 1998 Estimação do balanço térmico por radiação em vacas holandesas ao sol e à sombra. Proceedings of II Congresso Brasileiro de Biometeorologia. Goiânia, p.118-128.

Silva, R.G. 2000. Introdução á Bioclimatologia Animal. São Paulo. Nobel. 286p.

Silva, R.G.; La Scala Junior, N.; Tonhati, H. 2003. Radiative properties of the skin and hair coat of cattle and other animals. Transactions of the ASAE, 46: 913-918.

Sotomaior, C.S., Sotomaior, V.S. , Madeira, H. M. F. and ThomazSoccol, V. 2008. Prion protein gene polymorphisms in sheep in the state of Paraná, Brazil. Animal Genetics, 39, 659-661.

Stone, W.C., Chase, L.E. and Fox, D.G.. 1992 Field application of the Cornell Net carbohydrate and protein system in a progressive dairy herd. Proceedings Cornell Nutrition Conf., Ithaca, p.168172.

Swenson, M. J., Reece, W. O. 1996. Dukes, physiology of domestic animals. $11^{\text {th }}$ ed. Guanabara Koogan, Rio de Janeiro, Brazil.

Turner, H.G. 1984 Variation in rectal temperature of cattle in a tropical environment and its relation to growth rate. Animal Production, 38, 417-427.

Turnpenny, J.R., Wathes, C.M., Clark, J.A., McArthur, A.J. 2000 Thermal balance of livestock 2. Applications of a parsimonious model. Agricultural and Forest Meteorology, 101, 29-52.

West, J.W., 2003. Effects of heat stress on production in dairy cattle, Journal Dairy Science, 86, 2131-2144

Yeates, N.T.M. 1954 Environmental control of coat changes in cattle. Nature, 174:609-610.

Yeates, N.T.M. 1955 Photoperiodicity in cattle I. Seasonal changes in coat character and their importance in heat regulation. Australian Journal of Agricultural Research, 6, 991-903. 